\title{
UPAYA PENINGKATAN KEUNGGULAN BERSAING USAHA MIKRO KECIL DAN MENENGAH (UMKM) DI KOTA MEDAN DI MASA PANDEMI COVID 19
}

\author{
Esty Pudyastuti \\ Universitas IBBI Medan \\ Ahmad Saputra \\ Universitas IBBI Medan \\ estysoetardjo4@gmail.com \\ saputra_damha@yahoo.com
}

\begin{abstract}
Abstrak
Penelitian ini bertujuan untuk mengoptimalkan potensi UMKM dengan meningkatkan daya saingnya dimasa pandemi covid-19. UMKM memiliki peranan penting terhadap perekonomian Indonesia, karena lebih dari $90 \%$ pelaku usaha di Indonesia merupakan UMKM. UMKM merupakan salah satu potensi yang berperan dalam pertumbuhan ekonomi daerah. Untuk dapat mengoptimalkan potensinya, UMKM harus memiliki kualitas strategi yang tepat, serta didukung oleh kebijakan pemerintah. Penelitian ini dilakukan di beberapa UMKM yang berada di kota Medan dengan menggunakan variabel penelitian orientasi kewirausahaan, kualitas strategi, keunggulan bersaing, dan kinerja pemasaran. Metode penelitian yang digunakan berupa metode deskriptif kuantitatif. Populasi dalam penelitian ini adalah para pengelola dan pemilik sekaligus pengelola UMKM. Jumlah sampel 128 responden. Teknik analisis yang digunakan dalam penelitian ini adalah dengan teknik Structural Equation Modeling (SEM) paket software AMOS. Dari hasil pengujian hipotesis terbukti orientasi kewirausahaan berpengaruh signifikan terhadap kinerja pemasaran dengan rasio kritis 2,415. Kualitas strategi berpengaruh signifikan terhadap kinerja pemasaran dengan nilai rasio kritis 3,646. Orientasi kewirausahaan berpengaruh signifikan terhadap keunggulan bersaing dengan nilai rasio kritis 2,896. Kualitas strategi berpengaruh signifikan terhadap keunggulan bersaing dengan nilai critical ratio 6.439. Keunggulan kompetitif berpengaruh signifikan terhadap kinerja pemasaran dengan nilai crtical ratio 2.532 .
\end{abstract}

Kata Kunci: Orientasi Kewirausahaan, Kualitas Srategi, Keunggulan Bersaing, Kinerja Pemasaran.

\section{Pendahuluan}

Pada era globalisasi, kondisi persaingan usaha, baik pasar domestik maupun pasar internasional sangat ketat. Terlebih pada kondisi seperti saat ini di masa pandemi covid-19 memberikan dampak ke banyak sektor, antara lain sektor ekonomi. Kondisi ini dirasakan juga oleh para pelaku usaha kecil dan menengah yang mengalami krisis ekonomi.

Pandemi covid-19 bukan hanya menyebabkan masalah di bidang kesehatan, namun berdampak pula pada kondisi perekonomian negara. UMKM mengalami dampak terparah dari kondisi pandemi covid-19 ini. Banyak UMKM yang terpaksa menutup usahanya akibat dari 
berbagai permasalahan yang muncul di masa pandemi covid-19. UMKM merupakan penopang perekonomian Indonesia yang cukup besar. Mengingat sektor ini juga berkontribusi sebesar $60 \%$ terhadap GDP Nasional dan menyerap 97\% tenaga kerja, pemerintah telah membuat berbagai kebijakan untuk menstimulus UMKM agar kuat dan mampu bertahan.

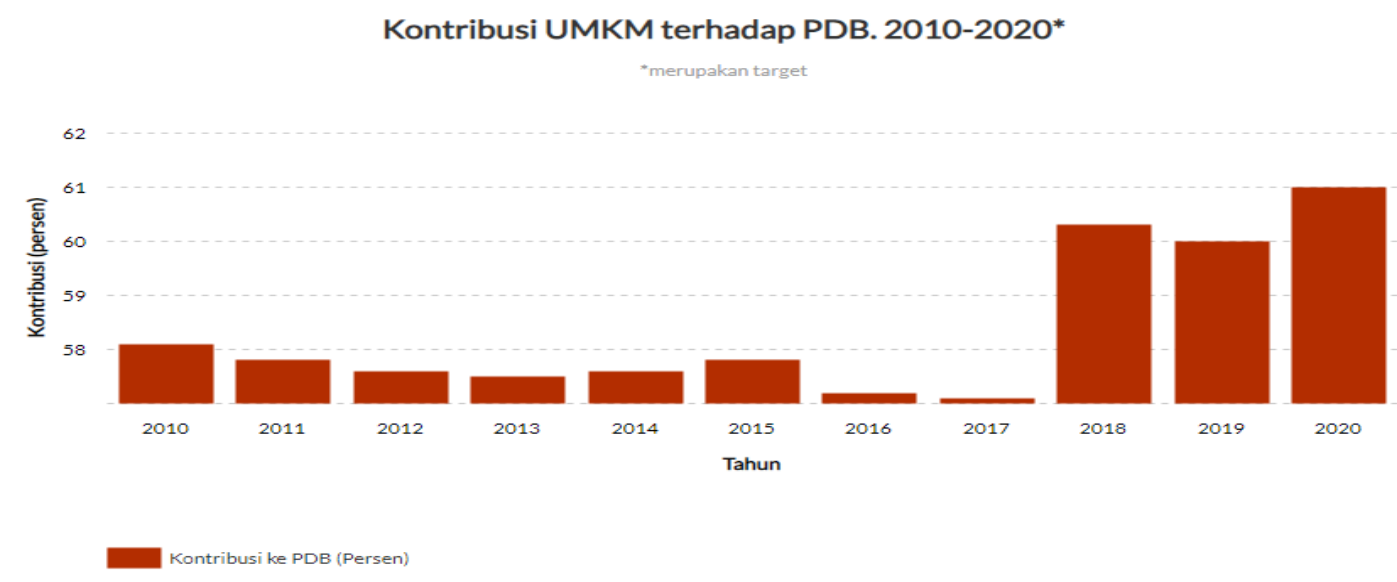

Gambar 1. Kontribusi UMKM Terhadap PDB

lokadata

Perusahaan yang ingin berkembang atau bertahan dalam satu lingkungan bisnis, harus dapat memberikan sesuatu, baik barang maupun jasa yang bernilai lebih tinggi dari pesaing. Nilai lebih ini tidak hanya diukur dengan harga yang lebih murah saja, akan tetapi kualitas, pelayanan, dan lainnya, sesuai dengan prinsip dasar pemasaran yang berorientasi kepada pelanggannya (customer oriented). Lingkungan bisnis yang berubah menuntut perusahaan semakin berorientasi pada pasar (market orientation). Perusahaan yang berorientasi pasar akan menganggap konsumen sebagai raja. Perusahaan yang mengerti keinginan konsumen sekaligus mampu memuaskan konsumen akan memenangkan persaingan. Semakin kompetitif suatu usaha, kemampuan orientasi pasar perusahaan akan semakin krusial.

Kinerja pemasaran merupakan bagian penting dari kinerja perusahaan karena kinerja perusahaan dapat dilihat dari kinerja pemasarannya. Kinerja pemasaran adalah konsep untuk mengukur prestasi pemasaran suatu perusahaan. Setiap perusahaan perlu mengetahui capaian prestasinya sebagai gambaran dari keberhasilan usahanya dalam persaingan pasar.

Di era globalisasi, setiap perusahaan dituntut untuk saling bersaing agar dapat mempertahankan usahanya. Persaingan yang tidak terkendali seringkali memerikan dampak negatif bagi dunia usaha. Untuk dapat berkembang, UMKM harus mampu mengoptimalkan potensi untuk meningkatkan daya saingnya, karena dalam menjalankan usahanya, UMKM akan selalu menghadapi persaingan. Dalam menjalankan bisnisnya, persaingan merupakan kondisi yang tidak dapat dihindari oleh UMKM. Beberapa masalah yang sering dihadapi UMKM adalah ketersediaan modal, pemasaran, kurangnya pengetahuan dan rendahnya kualitas sumber daya manusianya. Pengetahuan yang dimiliki sumber daya manusia merupakan faktor penting untuk meningkatkan daya saing perusahaan. Faktor ini merupakan kelemahan terbesar dari usaha mikro kecil dan menengah. Menurut (Muttaqien, 2008), rendahnya penguasaan pengetahuan pada UKM dan koperasi dipengaruhi faktor internal dan faktor eksternal.

Faktor-faktor tersebut diperparah dengan kondisi pandemi-covid 19. Dampak pandemi di sektor ekonomi tentunya tidak hanya dirasakan oleh pelaku ekonomi besar, tapi juga sangat terasa bagi pelaku UMKM. Terjadinya penurunan penjualan, bahan baku produk yang sulit 
diperoleh, dan kesulitan dalam pemasaran merupakan kendala yang dihadapi para pelaku UMKM, khususnya di Kota Medan. Menurut Ketua Kewirausahaan UKM Diskop Sumatera Utara bahwa kondisi UMKM di Sumatera Utara saat ini tidak baik. Hal tersebut dilihat dari menurunnya pendapatan UMKM sehingga terpaksa merumahkan karyawannya. Inilah masalah yang dihadapi UMKM saat ini. Saat ini sedikitnya ada 672.000 UMKM dan 7.700 koperasi di Sumatera Utara yang terdampak pandemi covid-19. Jumlah tersebut tersebar di seluruh kabupaten/kota di Sumatera Utara.

Dari total 960.000 UMKM di provinsi Sumatera Utara, jumlah UMKM yang terkena dampak pandemi covid-19 sebanyak 672.000 yang berada di 33 kabupaten/kota. Beberapa masalah yang menyebabkan terpuruknya UMKM dan koperasi di provinsi Sumatera Utara antara lain, pertama, UMKM dan koperasi mengalami penurunan yang signifikan karena menurunnya permintaan masyarakat. Kedua, bahan baku sulit didapatkan UMKM dan koperasi, karena banyak perusahaan penghasil bahan baku yang menutup usahanya. Ketiga, adalah terganggunya distribusi bahan baku produksi, dan keempat adalah para pelaku UMKM mengalami kesulitan mencari akses pembiayaan terlebih saat pandemi ini.

Faktor lain yang menyebabkan UMKM ini tidak mampu bersaing antara lain kualitas sumber daya manusia ditinjau dari motivasi dan tingkat pendidikannya, kurangnya pelatihan yang diperuntukkan bagi karyawan, sulitnya mencari pasar potensial, dan kurangnya promosi yang dilakukan.

\section{Landasan Teori dan Pengembangan Hipotesis}

\section{Orientasi Kewirausahaan}

Orientasi wirausaha merupakan karakteristik dan nilai yang dianut oleh wirausaha itu sendiri yang merupakan sifat pantang menyerah, berani mengambil resiko, kecepatan dan fleksibilitas(Liao \& Sohmen, 2001). Orientasi kewirausahaan memegang peranan penting dalam meningkatkan kinerja usaha. Menurut (Porter, 2008), orientasi kewirausahaan sebagai strategi benefit perusahaan untuk dapat berkompetisi secara lebih efektif di dalam market place yang sama.

Orientasi kewirausahaan yang tergambar dari sikap penuh inovasi, proaktif dan keberanian mengambil resiko diyakini mampu meningkatkan kinerja perusahaan. Hal ini diperkuat oleh pendapat (Covin \& Slevin, 1989); (Wiklund, 1999) yang menjelaskan bahwa orientasi kewirausahaan yang semakin tinggi dapat meningkatkan kemampuan perusahaan dalam memasarkan produknya menuju kinerja usaha yang lebih baik.

Hambatan resiko merupakan factor kunci yang membedakan perusahaan dengan jiwa wirausaha atau tidak. Orientasi kewirausahaan meningkatkan kinerja bisnis (Wardi, 2017).

\section{Kualitas Strategi}

Salah satu kunci keberhasilan perusahaan adalah kualitas strategi. Salah satu fokus perhatian pengelolaan sistem adalah pada proses. Pengembangan strategi merupakan proses membuat strategi untuk mencapai keunggulan. Proses yang bermutu seharusnya menjadi perhatian bersama dalam manajemen. Hal tersebut berarti pengelolaan proses diharapkan dapat menampilkan sebuah proses yang bermutu. Oleh karena itu, strategi yang dimunculkan melalui sebuah proses yang bermutu akan menghasilkan strategi yang bermutu pula (Ferdinand, 2000)

Menurut (Hitt et al., 2011) proses strategi mencakup elemen dasar: (1) Pengamatan lingkungan, (2) Perumusan strategi, (3) Implementasi strategi, dan (4) Evaluasi dan pengendalian. Strategi yang berkualitas adalah strategi yang dibangun dengan perencanaan, implementasi, dan evaluasi yang berkualitas. Konsep dasar analisis SWOT (Strenght, 
Weakness, Threat and Opportunity) adalah anteseden sebuah proses formulasi strategi yang mendalam terhadap situasi dan dapat menentukan posisi strategis instrumen-instrumen yang digunakan (Ferdinand, 2000).

\section{Keunggulan Bersaing}

Keunggulan bersaing menurut (Zimmerer \& Scarborough, 2008) adalah sekumpulan faktor yang membedakan perusahaan kecil dari para pesaingnya dan memberikannya posisi unik di pasar sehingga lebih unggul dari pada pesaingnya. (Mardiyono \& Sugiyarti, 2015) yang menjelaskan bahwa keunggulan bersaing (competitive advantage) adalah jantung kinerja pemasaran untuk menghadapi persaingan. Keunggulan bersaing diartikan sebagai cara menguntungkan dari perusahaan yang melakukan kerjasama untuk menciptakan keunggulan bersaing yang lebih efektif.

Keunggulan bersaing merupakan posisi yang masih dilakukan organisasi sebagai usaha mengalahkan pesaing. Pendekatan resources based (RB) memandang aktivitas ekonomi dari sisi pemanfaatan sumber daya dan kapabilitasnya, bukan menurut pasar yang dilayani. Pemanfaatan sumber daya dan kapabilitas ini dengan maksud membangun daya saing yang diarahkan kepada usaha-usaha menangkap berbagai peluang mengatasi berbagai ancaman dalam persaingan, sehingga dari kondisi ini dibangun strategi untuk menghambat para pesaing berupa kesulitan untuk ditiru (barriers to imitation), (Syafar, 2004)

\section{Kinerja Pemasaran}

Penelitian Indrajit (dalam (Waluyo, 2008) menyatakan kinerja pemasaran diukur menggunakan kepuasan pelanggan, motivasi kerja, sistem informasi, volume penjualan, pertumbuhan pelanggan, pertumbuhan penjualan.

(Lee, 2011) menggunakan pengukuran kinerja keuangan dan bukan keuangan. Kinerja keuangan ditunjukkan oleh peningkatan pendapatan return on sales, profitability, pertumbuhan penjualan, perbaikan produktivitas kerja, dan perbaikan biaya produksi. Sedangkan kinerja bukan keuangan diukur dengan peningkatan aset kepuasan pelanggan, pertumbuhan pelanggan, kepuasan karyawan, kualitas produk dan jasa serta reputasi perusahaan. (Lee, 2011) menyatakan bahwa kinerja dapat diukur melalui kinerja keuangan (financial performance) yang terdiri dari ROI, ROE, dan ROA serta kinerja pasar (market performance) yang terdiri dari tingkat petumbuhan penjualan dan tingkat pertumbuhan konsumen. Terdapat beberapa cara untuk mengukur kinerja perusahaan, yaitu pertumbuhan dalam penjualannya, yaitu menunjukkan peningkatan pelanggan yang dapat menerima produk perusahaan. Return On Equity (ROE), yaitu mengindikasikan keefektifan manajemen dalam menghasilkan pengembalian dana yang diinvestasikan oleh pemegang saham.

Berdasarkan uraian di atas disusun kerangka konseptual sebagai berikut:

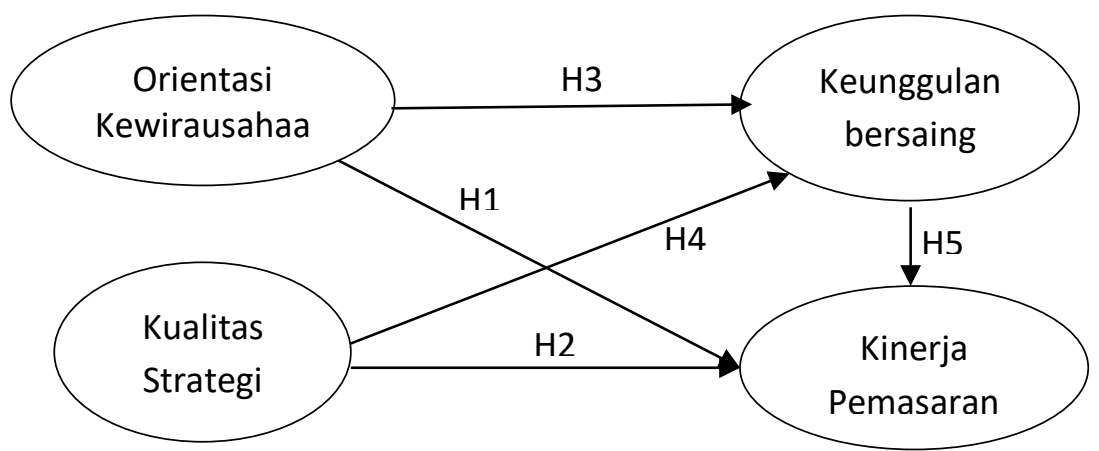

Gambar 2. Kerangka Konseptual 


\section{Pengembangan Hipotesis}

\section{Hubungan Orientasi Kewirausahaan dan Kinerja Pemasaran}

Pengujian empiris yang dilakukan untuk mengetahui hubungan kausalitas antara orientasi wirausaha dan kinerja organisasi telah menggunakan beberapa cara yang berbeda. (Covin \& Slevin, 1989) mengatakan bahwa koefisien korelasi antara wirausaha (sebagai pengambilan resiko, inovasi produk, dan sikap proaktif) dan kinerja perusahaan.

Perusahaan dengan orientasi kewirausahaan yang tinggi juga memiliki tingkat kinerja yang lebih tinggi. Penelitian (Rauch et al., 2009) menunjukkan orientasi kewirausahaan memiliki hubungan cukup besar dengan kinerja organisasi. Hubungan positif ini berlaku juga untuk kinerja non-keuangan dan keuangan. Berdasarkan penjelasan di atas maka hipotesis dirumuskan sebagai berikut:

H1: Semakin tinggi orientasi kewirausahaan maka kinerja pemasaran akan semakin tinggi.

\section{Hubungan Kualitas Strategi dengan Kinerja Pemasaran}

Salah satu kunci keberhasilan perusahaan adalah kualitas strategi. Salah satu fokus perhatian pengelolaan sistem adalah pada proses. Pengembangan strategi merupakan proses membuat strategi untuk mencapai keunggulan. Proses yang berkualitas hendaknya menjadi perhatian bersama dalam manajemen. Oleh karena itu, strategi yang dimunculkan melalui sebuah proses yang bermutu akan menghasilkan strategi yang bermutu pula(Ferdinand, 2000). Tindakan startegis efektif dilakukan dalam konteks formulasi dan implementasi strategi yang diintegrasikan dengan cermat akan menghasilkan output strategis yang diinginkan (Hitt et al., 2011).

Resource-Based Theory (Barney, 1991) menyatakan bahwa kinerja organisasi umumnya, dan kinerja pemasaran khususnya, bergantung pada antara lain bagaimana kemampuan perusahaan mengembangkan berbagai company-specific strategic resources. Sumber daya spesifik ini dapat diartikulasikan melalui berbagai atribut strategis seperti tingkat diferensiasi produk yang dihasilkan, keunggulan teknologi yang digunakan, efektivitas instrumen promosi yang dikembangkan, maupun instrumen-instrumen penjualan seperti efektivitas profesional tenaga penjualan. Berdasarkan penjelasan di atas maka hipotesis dirumuskan sebagai berikut:

H2: Semakin tinggi kualitas strategi maka kinerja pemasaran akan semakin tinggi.

\section{Hubungan Orientasi Kewirausahaan dengan Keunggulan Bersaing}

Perusahaan yang memiliki orientasi kewirausahaan akan mencapai target pasar dan posisi pasar yang lebih baik dibandingkan para pesaing. (Kumalaningrum, 2012) menyatakan perusahaan selalu mengamati perubahan pasar dan melakukan respon dengan cepat terhadap perubahan tersebut. Keberanian perusahaan mengambil resiko dan kemampuannya untuk proaktif, menjadikan perusahaan mempunyai kemampuan menciptakan produk inovatif mendahului para pesaingnya sehingga memiliki keunggulan bersaing dan akan mampu memuaskan pelanggan serta mengidentifikasi faktor-faktor yang mempengaruhi para pelanggan. Oleh karena itu hipotesis dirumuskan sebagai berikut:

H3: Semakin tinggi orientasi kewirausahaan maka keunggulan bersaing perusahaan akan semakin tinggi.

\section{Hubungan Kualitas Strategi Dengan Keunggulan Bersaing}

Pengembangan strategi perusahaan akan memungkinkan perusahaan mencapai keunggulan kompetitif. Pengelolaan proses perancangan strategi yang bermutu diharapkan 
dapat menampilkan sebuah proses yang bermutu pula. Oleh karena itu, strategi yang dimunculkan melalui sebuah proses yang bermutu akan menghasilkan strategi yang bermutu pula(Ferdinand, 2000). Tindakan startegis efektif dilakukan dalam konteks formulasi dan implementasi strategi yang diintegrasikan dengan cermat akan menghasilkan output strategis yang diinginkan (Hitt et al., 2011). Strategi perusahaan selalu diarahkan untuk menghasilkan kinerja pemasaran (seperti volume penjualan dan tingkat pertumbuhan penjualan) yang baik dan juga kinerja keuangan yang baik. Kinerja pemasaran yang baik dinyatakan dalam tiga besaran utama nilai, yaitu nilai penjualan, pertumbuhan penjualan, dan porsi pasar.(Ferdinand, 2000).

(Wahyono, 2002) menjelaskan bahwa pertumbuhan penjualan akan bergantung pada berapa jumlah pelanggan yang telah diketahui tingkat konsumsi rata-ratanya yang bersifat tetap. Nilai penjualan menunjukkan berapa rupiah atau berapa unit produk yang berhasil dijual oleh perusahaan kepada konsumen atau pelanggan. Nilai penjualan yang semakin tinggi mengindikasikan produk yang dijual perusahaan semakin tinggi. Sedangkan porsi pasar menunjukkan seberapa besar kontribusi produk yang ditangani dapat menguasai pasar untuk produk sejenis dibandingkan para competitor. Berdasarkan uraian di atas maka hipotesis dirumuskan sebagai berikut

H4: Semakin tinggi kualitas strategi maka keunggulan strategi akan semakin tinggi.

\section{Hubungan Keunggulan Bersaing Dengan Kinerja Pemasaran}

Menurut (Wahyono, 2002), inovasi yang berkelanjutan dalam suatu perusahaan merupakan kebutuhan dasar yang pada gilirannya akan mengarah pada terciptanya keunggulan kompetitif. Secara konvensional, inovasi diartikan sebagai terobosan yang berkaitan dengan produk-produk baru. Inovasi juga mencakup penerapan gagasan atau proses yang baru. Inovasi dipandang sebagai mekanisme perusahaan dalam beradaptasi dengan lingkungannya yang dinamis.

Perubahan-perubahan yang terjadi dalam lingkungan bisnis memaksa perusahaan mampu menciptakan pemikiran-pemikiran dan gagasan-gagasan baru, dan juga menawarkan produk-produk inovatif. Inovasi semakin memiliki arti penting bukan hanya sebagai alat untuk mempertahankan kelangsungan hidup perusahaan, melainkan juga agar dapat memenangkan persaingan. Tidak menawarkan desain yang unik atau salah memperkirakan keinginan dan kebutuhan pelanggan dapat menyebabkan gagalnya inovasi produk.

Inovasi produk diharapkan mampu memberikan nilai tambah dibanding produk sejenis yang berhasil dijual oleh perusahaan. Porsi pasar menunjukkan seberapa besar kontribusi produk yang ditangani dapat menguasai pasar untuk produk sejenis dibandingkan para kompetitor. Kemampuan perusahaan dalam mengolah dan memanfaatkan sumber daya dan modal yang dimilikinya dapat meningkatkan keunggulan bersaing. Perusahaan yang mampu mencipatakan keunggulan bersaing akan memiliki kekuatan untuk bersaing dengan perusahaan lain karena produknya tetap diminati oleh pelanggan. Dengan demikian keunggulan bersaing memiliki pengaruh positif terhadap peningkatan kinerja pemasaran perusahaan yang diperoleh oleh perusahaan. Hipotesis yang diajukan dalam penelitian ini adalah:

H5: Semakin tinggi keunggulan bersaing maka kinerja pemasaran semakin tinggi 


\section{Metode Penelitian}

\section{Populasi}

Populasi adalah kumpulan individu atau obyek penelitian yang memiliki kualitas serta ciri-ciri yang ditetapkan. Populasi pada penelitian ini adalah UMKM di Kota Medan dengan elemen populasinya yaitu pengelola dan pemilik sekaligus pengelola usaha yang telah beroperasi selama minimal dua tahun.

\section{Sampel}

Sampel adalah bagian dari sejumlah karakteristik yang dimiliki oleh populasi yang digunakan untuk penelitian. Ukuran sampel yang disarankan (Hair J.F, 1995) yang sesuai untuk alat analisis SEM adalah 100-200 responden, yang bertujuan agar dapat digunakan dalam mengestimasi interpretasi dengan SEM. Jumlah sampel dalam penelitian ini sebanyak 128 responden.

\section{Metode Pengumpulan Data}

Untuk mengumpulkan data penelitian, menggunakan kuesioner. Kuesioner merupakan instrumen yang digunakan untuk mengumpulkan data, berisikan pertanyaan yang dikembangkan untuk mengukur variabel-variabel yang menjadi objek penelitian. Untuk mengukur masing-masing variabel yang digunakan adalah skala interval. Skala interval merupakan alat untuk mengukur data yang menghasilkan rentang nilai yang ditentukan dan memiliki makna, yang memungkinkan untuk diuji dengan alat uji statistik parametrik. Teknik yang digunakan dalam menentukan skala penelitian ini agree-disagree scale, yakni dengan mengembangkan pertanyaan yang menghasilkan jawaban setuju - tidak setuju dalam rentang nilai (Ferdinand, 2011). Dalam penelitian ini rentang nilai yang digunakan antara angka 1 sampai angka 7. Angka 1 menunjukkan jawaban sangat tidak setuju dan angka 7 menunjukkan jawaban sangat setuju.

\section{Teknik Analisis Data}

Teknik analisis yang dipakai untuk menginterpretasikan dan menganalisis data dalam penelitian ini adalah Structural Equation Model (SEM) yang dioperasikan melalui program AMOS.

\section{Pembahasan}

\section{Uji Validitas dan Reliabilitas}

Kuesioner yang digunakan dalam penelitian ini dalam bentuk pertanyaan tertutup. Pertanyaan tertutup merupakan pengukuran terhadap dimensi yang digunakan dalam penelitian yang perlu diuji validitas dan reliabilitasnya. Hasil uji validitas dan reliabilitas disajikan dalam tabel berikut:

Tabel 1. Hasil Uji Validitas dan Reliabilitas

\begin{tabular}{|l|l|c|c|c|c|}
\hline No & \multicolumn{1}{|c|}{ Variabel } & $\begin{array}{c}\text { Corrected } \\
\text { Item Total } \\
\text { Correlation }\end{array}$ & $\begin{array}{c}\text { Cronbach } \\
\text { Alpha }\end{array}$ & Batasan & Kesimpulan \\
\hline \multirow{2}{*}{$\mathbf{1}$} & Orientasi kewirausahaan & - & 0,806 & Diatas 0,6 & Reliabel \\
\cline { 2 - 6 } & Menemukan ide baru & 0.469 & & Diatas 0,203 & Valid \\
\cline { 2 - 6 } & $\begin{array}{l}\text { Menggunakan teknologi } \\
\text { baru }\end{array}$ & 0.411 & & Diatas 0,203 & Valid \\
\cline { 2 - 6 } & $\begin{array}{l}\text { Berani meluncurkan produk } \\
\text { baru }\end{array}$ & 0.275 & & Diatas 0,203 & Valid \\
\hline
\end{tabular}




\begin{tabular}{|l|l|c|c|c|c|}
\hline \multirow{4}{*}{2} & Berani memasuki pasar baru & 0.398 & & Diatas 0,203 & Valid \\
\cline { 2 - 6 } & Menerapkan strategi baru & 0.505 & & Diatas 0,203 & Valid \\
\hline \multirow{4}{*}{$\mathbf{3}$} & Kualitas strategi & - & 0,830 & Diatas 0,6 & Reliabel \\
\cline { 2 - 6 } & Kualitas perencanaan & 0.589 & & Diatas 0,203 & Valid \\
\cline { 2 - 6 } & Kualitas proses & 0.786 & & Diatas 0,203 & Valid \\
\cline { 2 - 6 } & Kualitas evaluasi & 0.584 & & Diatas 0,203 & Valid \\
\hline & Kinerja pemasaran & & 0,816 & Diatas 0,6 & Reliabel \\
\cline { 2 - 6 } & Pertumbuhan penjualan & 0.696 & & Diatas 0,203 & Valid \\
\cline { 2 - 6 } & Perluasan Pasar & 0.710 & & Diatas 0,203 & Valid \\
\cline { 2 - 6 } & Pertumbuhan pelanggan & 0.616 & & Diatas 0,203 & Valid \\
\hline \multirow{4}{*}{$\mathbf{b a r u}$} & Keunggulan Bersaing & - & 0,913 & Diatas 0,6 & Reliabel \\
\cline { 2 - 6 } & Bernilai & 0.832 & & Diatas 0,203 & Valid \\
\cline { 2 - 6 } & Susah tergantikan & 0.867 & & Diatas 0,203 & Valid \\
\cline { 2 - 6 } & Unik & 0.702 & & Diatas 0,203 & Valid \\
\cline { 2 - 6 } & Sulit ditiru & 0.767 & & Diatas 0,203 & Valid \\
\hline
\end{tabular}

(Sumber: data diolah, 2021)

Hasil pengujian validitas dan reliabilitas menunjukkan bahwa instrumen penelitian dapat memenuhi syarat karena sesuai dengan kriteria cronbach alpha 0,6 serta cut-off 1,96 dengan (alfa) $\alpha=0,5$.

\section{Hasil Uji Asumsi SEM}

\section{Pengujian Asumsi Atas Normalitas Data}

Analisis normalitas data mempertimbangkan bahwa model persamaan struktural peka terhadap distribusi data, khususnya penyimpangan normalitas multivariat. Oleh karena itu, perlu dilakukan pengujian terhadap normalitas data. Hasil analisis AMOS terhadap normalitas data dapat dilihat pada tabel berikut:

Tabel 2. Assessment of normality (Group number 1)

\begin{tabular}{|c|cccccc|}
\hline Variable & Min & Max & skew & c.r. & kurtosis & c.r. \\
\hline OK1 & 4.000 & 9.000 & -.077 & -.449 & -.680 & -1.978 \\
OK2 & 4.000 & 10.000 & .074 & .433 & -.680 & -1.977 \\
OK3 & 4.000 & 9.000 & .047 & .271 & -.863 & -2.509 \\
OK4 & 4.000 & 10.000 & .101 & .589 & -.508 & -1.477 \\
OK5 & 4.000 & 9.000 & -.105 & -.611 & -.468 & -1.360 \\
KS1 & 4.000 & 9.000 & -.105 & -.611 & -.468 & -1.360 \\
KS2 & 4.000 & 9.000 & -.033 & -.193 & -.688 & -2.001 \\
KS3 & 4.000 & 9.000 & .199 & 1.159 & -.531 & -1.545 \\
KP1 & 3.000 & 9.000 & .101 & .586 & -.433 & -1.260 \\
KP2 & 3.000 & 10.000 & .019 & .108 & -.110 & -.320 \\
KP3 & 4.000 & 9.000 & .034 & .198 & -.634 & -1.843 \\
KB1 & 4.000 & 10.000 & -.274 & -1.595 & -.152 & -.441 \\
KB2 & 4.000 & 9.000 & .031 & .181 & -.185 & -.539 \\
KB3 & 4.000 & 9.000 & .230 & 1.339 & -.573 & -1.667 \\
\hline
\end{tabular}


INOBIS: Jurnal Inovasi Bisnis dan Manajemen Indonesia

Volume 04, Nomor 03, Juni 2021

Dita Rimbawati Dewi, Dian Anita Nuswantara

\begin{tabular}{|c|cccccc|}
\hline Variable & Min & Max & skew & c.r. & kurtosis & c.r. \\
\hline KB4 & 4.000 & 9.000 & .113 & .655 & -.678 & -1.971 \\
Multivariate & & & & & 8.413 & 2.654 \\
\hline
\end{tabular}

(Sumber: data diolah, 2021)

Hasil perhitungan normalitas data seperti pada tabel 2 terlihat hampir semua variabel memiliki nilai kritis dibawah 1,96, terdapat 5 indikator yang memiliki nilai kritis diatas 1,96 tetapi lebih kecil dari 2,58 untuk tingkat kesalahan 10\%. Beberapa pakar SEM menyatakan bahwa indeks skewness yang lebih besar dari 3 menunjukkan kemencengan yang ekstrim ((Kline.R.B, 2005), (Hair J.F, 1995), karena itu dapat dikatakan bahwa data berada pada rentang normal.

\section{Evaluasi Multikolinearitas Full Model}

Pengamatan terhadap determinan dari matriks kovarian sampel perlu dilakukan untuk mengetahui apakah terdapat multikolinieritas atau singularitas dalam kombinasi variabelvariabel penelitian. Berdasarkan pendekatan statistik, nilai determinan yang terlalu kecil atau mendekati nol mengindikasikan bahwa penaksiran parameter dari model adalah tidak bagus karena menunjukkan standar error yang besar. Dalam penelitian ini nilai determinan dari matriks kovarian sampel adalah relative kecil yaitu 1,69 diatas nol, maka dapat disimpulkan tidak ada multikoliniaritas maupun singularitas yang berarti pada data.

\section{Pengujian Evaluasi Asumsi SEM Dalam Model Struktural}

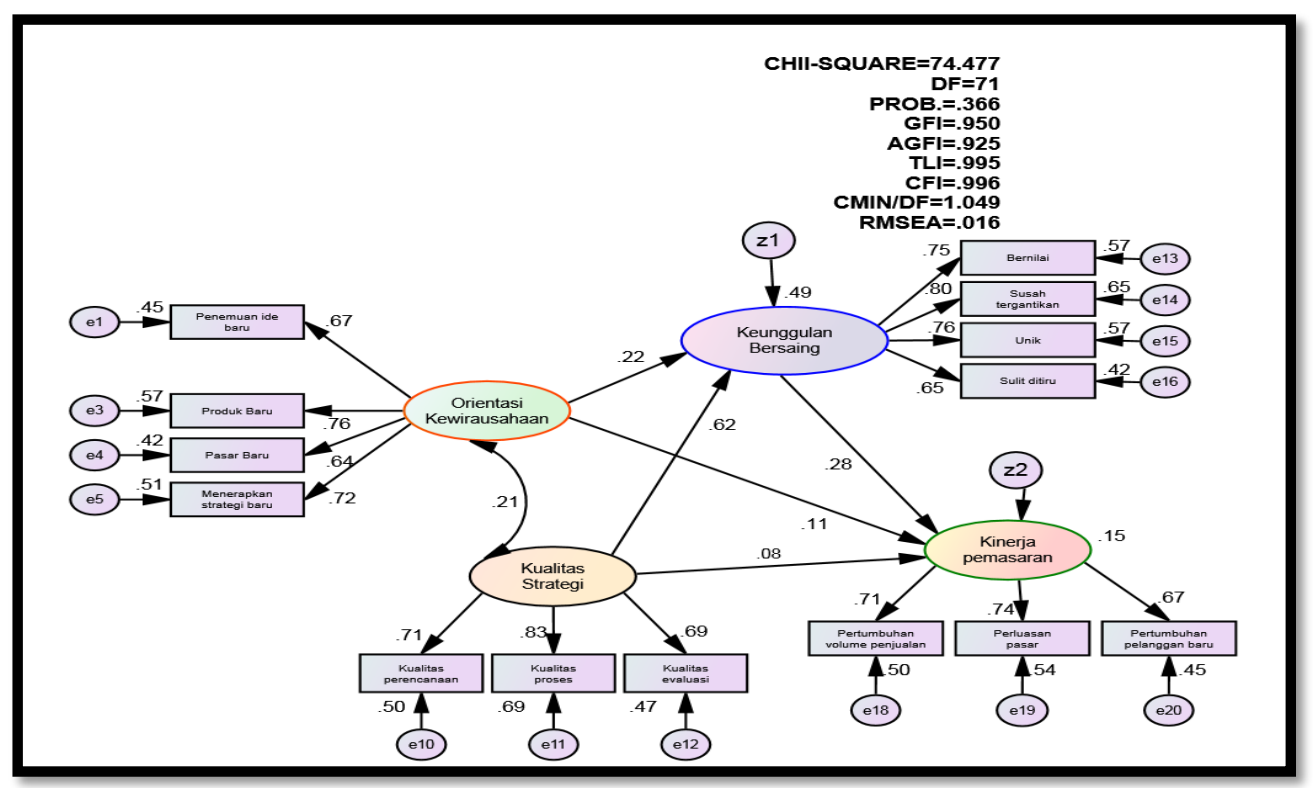

Gambar 3. Full model revisi

(Sumber: Data yang diolah 2021)

Hasil analisis mendukung hipotesis yang menyatakan bahwa model penelitian ini sesuai dengan data atau fit terhadap data. Indeks statistik chi-square digunakan untuk membandingkan matriks kovarian yang diprediksi dengan matriks kovarian yang diobservasi. Hasil penelitian kelayakan model menunjukkan nilai chi-square relatif kecil ( $\mathrm{X}^{2}=74,477$ dengan $71 \mathrm{df}$ ). Nilai probabilitas sebesar 0,366 jauh di atas dari 0,05 yang direkomendasikan. Indeks pengujian kelayakan model secara ringkas disajikan pada tabel 3 berikut: 
Tabel 3. Indeks Kelayakan Model Structural/Path

\begin{tabular}{|l|llllllll|}
\hline Keterangan & Chi-square & Probabilitas & GFI & AGFI & CFI & TLI & $\begin{array}{l}\text { CMIN/ } \\
\text { DF }\end{array}$ & RMSEA \\
\hline Cut of Value & $\begin{array}{l}412,671 \\
(\alpha=0,05:\end{array}$ & $\geq 0,05$ & $\geq 0,90$ & $\geq 0,90$ & $\geq 0,95$ & $\geq 0,95$ & $\leq 2,00$ & $\leq 0,08$ \\
Hasil Analisis & $\begin{array}{l}\text { DF=0,367) } \\
74,477\end{array}$ & 0,366 & 0,950 & 0,925 & 0,996 & 0,995 & 1,049 & 0,016 \\
SF=0,72 & & Fit & Fit & Fit & Fit & Fit & Fit & Fit \\
\hline
\end{tabular}

(Sumber : Hasil olah data primer, 2021)

\section{Pengujian Hipotesis}

Setelah keseluruhan asumsi dapat dipenuhi, maka dilanjutkan dengan pengujian hipotesis. Pengujian hipotesis dilakukan berdasarkan nilai critical ratio (CR) dari suatu hubungan kausalitas seperti ditunjukkan pada tabel berikut :

Tabel 4. Hasil Penaksiran Parameter Full Model

\begin{tabular}{|c|c|c|c|c|c|c|c|}
\hline & & & Estimate & S.E. & C.R. & $\mathrm{P}$ & Label \\
\hline $\mathrm{KB}$ & $<--$ & $\mathrm{OK}$ & .245 & .085 & 2.896 & .004 & par_13 \\
\hline $\mathrm{KB}$ & $<---$ & KS & .644 & .100 & 6.439 & $* * *$ & par_14 \\
\hline KP & $<--$ & $\mathrm{OK}$ & .096 & .087 & 2.415 & .045 & par_11 \\
\hline KP & $<---$ & $\mathrm{KB}$ & .230 & .113 & 2.532 & .042 & par_12 \\
\hline KP & $<---$ & $\mathrm{KS}$ & .072 & .111 & 3.646 & .019 & par_16 \\
\hline KB 1 & $<--$ & $\mathrm{KB}$ & 1.000 & & & & \\
\hline KB2 & $<---$ & $\mathrm{KB}$ & 1.075 & .101 & 10.642 & $* * *$ & par_1 \\
\hline KB3 & $<--$ & $\mathrm{KB}$ & 1.007 & .100 & 10.119 & $* * *$ & par_2 \\
\hline KB4 & $<--$ & $\mathrm{KB}$ & .766 & .088 & 8.659 & $* * *$ & par_3 \\
\hline KP2 & $<--$ & $\mathrm{KP}$ & 1.194 & .164 & 7.288 & $* * *$ & par_4 \\
\hline OK5 & $<--$ & OK & 1.000 & & & & \\
\hline OK4 & $<--$ & $\mathrm{OK}$ & .847 & .109 & 7.731 & $* * *$ & par_5 \\
\hline OK3 & $<--$ & $\mathrm{OK}$ & 1.003 & .117 & 8.610 & $* * *$ & par_6 \\
\hline OK1 & $<--$ & $\mathrm{OK}$ & .907 & .114 & 7.953 & $* * *$ & par_7 \\
\hline $\mathrm{KS} 2$ & $<--$ & $\mathrm{KS}$ & 1.222 & .136 & 8.979 & $* * *$ & par_8 \\
\hline KS1 & $<--$ & $\mathrm{KS}$ & 1.085 & .129 & 8.401 & $* * *$ & par_9 \\
\hline KS3 & $<--$ & $\mathrm{KS}$ & 1.000 & & & & \\
\hline KP1 & $<--$ & $\mathrm{KP}$ & 1.104 & .152 & 7.258 & $* * *$ & par_10 \\
\hline KP3 & $<--$ & $\mathrm{KP}$ & 1.000 & & & & \\
\hline
\end{tabular}

(Sumber: Hasil analisis data, 2021)

\section{Pembahasan}

\section{Pengaruh orientasi kewirausahaan terhadap kinerja pemasaran}

$\mathrm{H}_{1}$ : semakin tinggi orientasi kewirausahaan maka kinerja pemasaran akan semakin tinggi.

Parameter estimasi pengujian pengaruh orientasi kewirausahaan terhadap kinerja pemasaran menunjukkan hasil signifikan dengan nilai critical ratio (CR) sebesar 2,415 dengan p-value (nilai probabilitas) sebesar 0,045. Nilai-nilai tersebut telah memenuhi persyaratan 
penerimaan hipotesis yaitu nilai $\mathrm{CR}>1,96$ dan pada tingkat signifikansi 0,05 dan nilai $p$ value $<0,05$, sehingga tidak ada alasan untuk menolak hipotesis 1 . Artinya pengaruh orientasi kewirausahaan terhadap kinerja pemasaran signifikan, dengan standardized estimation 0,096.

Hasil pengujian hipotesis ini mendukung hipotesis yang diajukan sehingga semakin tinggi orientasi kewirausahaan maka akan semakin tinggi kinerja pemasaran. Hasil penelitian ini mengidentifikasikan bahwa orientasi kewirausahaan merupakan kesatuan kemauan perusahaan untuk melakukan inovasi, proaktif terhadap perubahan pasar dan berani mengambil resiko.

\section{Pengaruh kualitas strategi terhadap kinerja pemasaran}

$\mathrm{H}_{2}$ : Semakin tinggi kualitas strategi maka kinerja pemasaran akan semakin tinggi.

Parameter estimasi pengujian pengaruh kualitas strategi terhadap kinerja pemasaran menunjukkan hasil signifikan dengan nilai critical ratio (CR) sebesar 3,646 dengan p-value (nilai probabilitas) sebesar 0,019. Nilai-nilai tersebut telah memenuhi persyaratan penerimaan hipotesis yaitu nilai CR> 1,96 dan pada tingkat signifikansi 0,05 dan nilai p-value <0,05, sehingga tidak ada alasan untuk menolak hipotesis 2. Artinya pengaruh kualitas strategi terhadap kinerja pemasaran signifikan, dengan standardized estimation 0,072. Hasil uji statistik ini memberikan bukti terhadap hipotesis yang diajukan, sehingga semakin tinggi kualitas strategi maka akan semakin tinggi kinerja pemasaran.

\section{Pengaruh orientasi kewirausahaan terhadap keunggulan bersaing}

$\mathrm{H}_{3}$ : Semakin tinggi orientasi kewirausahaan maka keunggulan bersaing perusahaan akan semakin tinggi.

Parameter estimasi pengujian menunjukkan hasil signifikan dengan nilai critical ratio (CR) sebesar 2,896 dengan $p$-value (nilai probabilitas) sebesar 0,004. Nilai-nilai tersebut telah memenuhi persyaratan penerimaan hipotesis yaitu nilai CR $>1,96$ dan pada tingkat signifikansi 0,05 dan nilai $p$-value $<0,05$, sehingga tidak ada alasan untuk menolak hipotesis 3 . Artinya pengaruh orientasi kewirausahaan terhadap keunggulan bersaing signifikan, dengan standardized estimation 0,245. Hasil pengujian hipotesis ini mendukung hipotesis yang diajukan sehingga semakin tinggi orientasi kewirausahaan maka akan semakin tinggi keunggulan bersaing.

\section{Pengaruh kualitas strategi terhadap keunggulan bersaing}

$\mathrm{H}_{4}$ : Semakin tinggi kualitas strategi maka keunggulan strategi akan semakin tinggi.

Parameter estimasi pengujian pengaruh kualitas strategi terhadap keunggulan bersaing menunjukkan hasil signifikan dengan nilai critical ratio (CR) sebesar 6,439 dengan p-value (nilai probabilitas) sebesar $* * *$. Nilai-nilai tersebut telah memenuhi persyaratan penerimaan hipotesis yaitu nilai CR> 1,96 dan pada tingkat signifikansi 0,05 dan nilai p-value $<0,05$, bahkan lebih kecil dari 0,01 sehingga hipotesis 4 diterima. Artinya pengaruh kualitas strategi terhadap keunggulan bersaing signifikan, dengan standardized estimation 0,644.

Hasil uji hipotesis ini membuktikan bahwa semakin tinggi kualitas strategi maka akan semakin tinggi keunggulan bersaing. Hasil penelitian ini mengindikasikan bahwa kualitas strategi adalah strategi perusahaan yang melibatkan seluruh bagian perusahaan dari bagian perencanaan, implementasi dan evaluasi, dengan strategi yang berkualitas akan meningkatkan daya saing perusahaan pada posisi unggul, artinya kualitas strategi menjadi kunci keberhasilan perusahaan. 


\section{Pengaruh keunggulan bersaing terhadap kinerja pemasaran}

$\mathrm{H}_{5}$ : Semakin tinggi keunggulan bersaing maka kinerja pemasaran semakin tinggi

Parameter estimasi pengujian pengaruh keunggulan bersaing terhadap kinerja pemasaran menunjukkan hasil signifikan dengan nilai critical ratio (CR) sebesar 2,532 dengan $p$-value (nilai probabilitas) sebesar 0,042. Nilai-nilai tersebut telah memenuhi persyaratan penerimaan hipotesis yaitu nilai $\mathrm{CR}>1,96$ dan pada tingkat signifikansi 0,05 dan nilai $p$ value $<0,05$, sehingga tidak ada alasan untuk menolak hipotesis 5. Artinya pengaruh keunggulan bersaing terhadap kinerja pemasaran signifikan dengan standardized estimation 0,230

\section{Kesimpulan}

Hasil penelitian secara empiris menunjukkan bahwa orientasi kewirausahaan dan kualitas strategi berpengaruh signifikan terhadap kinerja pemasaran. Hal ini mengindikasikan semakin tinggi tingkat orientasi kewirausahaan dan semakin berkualitas strategi yang dibangun oleh perusahaan, maka semakin meningkat kinerja pemasaran. Kemampuan perusahaan dalam melakukan inovasi baik inovasi proses maupun inovasi produk berdampak terhadap kinerja. Perusahaan juga harus mengembangkan kemampuannya dalam menyusun strategi karena semua output yang dihasilkan bermula dari strategi yang dibangun oleh perusahaan. Strategi yang komprehensif baik secara teoritis maupun empiris dapat mempengaruhi kinerja dan meningkatkan kualitas output. Orientasi kewirausahaan dan kualitas strategi juga memiliki pengaruh yang signifikan terhadap keunggulan bersaing. Hal ini menunjukkan bahwa peran keunggulan bersaing yang dimiliki oleh perusahaan sebagai akibat dari kemampuan orientasi kewirausahaan dan semakin baiknya kualitas strategi yang dirancang perusahaan. Kemampuan perusahaan dalam melakukan orientasi kewirausahaan dan menyusun strategi yang berkualitas berdampak pada kemampuan perusahaan dalam meningkatkan keunggulan bersaing. Secara empiris juga terbukti bahwa keunggulan bersaing berpengaruh signifikan terhadap kinerja pemasaran. Artinya bahwa semakin tinggi keunggulan bersaing, maka semakin meningkat kinerja pemasaran. Perusahaan yang terus memperhatikan perkembangan kinerjanya dan berusaha untuk meningkatkan kinerjanya tersebut, maka sebenarnya perusahaan sudah memiliki modal yang kuat untuk terus bersaing dengan perusahaan lain.

\section{Daftar Pustaka}

Barney, J. (1991). Firm Resources and Sustained Competitive Advantage. Journal of Management, 17(1). https://doi.org/10.1177/014920639101700108

Covin, J. G., \& Slevin, D. P. (1989). Strategic management of small firms in hostile and benign environments. Strategic Management Journal, https://doi.org/10.1002/smj.4250100107

Ferdinand, A. (2000). Manajemen Pemasaran: Sebuah Pendekatan Strategik. Universitas Diponegoro.

Ferdinand, A. (2011). Metode Penelitian Manajemen Pedoman Penelitian untuk Penulisan Skripsi, Tesis, dan Disertasi Ilmu Manajemen (3rd ed.). Universitas Diponegoro.

Hair J.F. (1995). Multivariate Data Analysis with Reading (4th ed.). Prentice Hall.

Hitt, M., Ireland, R., Sirmon, D., \& Trahms, C. (2011). Strategic entrepreneurship: Creating value for individuals, organizations, and society. Academy of Management Perspectives, 25(2). https://doi.org/10.5465/AMP.2011.61020802 
Kline.R.B. (2005). Principles and Practice of Structural Equation Modelling: methodology in the social science. In Methodology in the social sciences.

Kumalaningrum, M. P. (2012). LINGKUNGAN BISNIS, ORIENTASI KEWIRAUSAHAAN, ORIENTASI PASAR, DAN KINERJA USAHA MIKRO, KECIL DAN MENENGAH. Jurnal Riset Manajemen Dan Bisnis, 7(1). https://doi.org/10.21460/jrmb.2012.71.83

Lee, T. K. dan W. C. (2011). Entrepreuneurial Orientation and Competitive Advantage - The Mediation of Resource Value and Rareness. African Journal of Business Management, 5.

Liao, D., \& Sohmen, P. (2001). The Development of Modern Entrepreneurship in China. Spring, 1 .

Mardiyono, A., \& Sugiyarti, G. (2015). Analisis Kinerja Pemasaran pada Industri Kreatif di Kota Semarang (Studi Empiris Pada Produsen Kaos). Optimalisasi Peran Industri Kreatif Dalam Menghadapi Masyarakat Ekonomi ASEAN.

Muttaqien, A. (2008). Hubungan Antara Lingkungan Eksternal, Orientasi Strategik Dan Kinerja Perusahaan (Studi Empiris pada Usaha Manufaktur Menengah -Kecil di Kota Semarang). UNDIP.

Porter, M. E. (2008). Competitive Advantage (Keunggulan Bersaing). . Karisma Publishing Group.

Rauch, A., Wiklund, J., Lumpkin, G. T., \& Frese, M. (2009). Entrepreneurial orientation and business performance: An assessment of past research and suggestions for the future. Entrepreneurship: Theory and Practice, 33(3). https://doi.org/10.1111/j.15406520.2009.00308.x

Syafar, A. . (2004). Membangun Daya Saing Daerah melalui Kompetensi Khas (Distinctive Competence) Berbasis Komoditi Unggulan.

Wahyono. (2002). ORIENTASI PASAR DAN INOVASI : PENGARUHNYA TERHADAP KINERJA PEMASARAN (Studi Kasus pada Industri Meubel di Kabupaten Jepara). JURNAL SAINS PEMASARAN INDONESIA, 1(1).

Waluyo, M. (2008). Permodelan Variabel Supplier, Manufactur, Distributor dan Customer Terhadap Kinerja Pemasaran yang Berorientasi Pada Keunggulan Bersaing Berkelanjutan (Studi Kasus Pada Asosiasi \& Pengrajin Sepatu Sandal Wedoro). UPN.

Wardi, Y. (2017). Orientasi Kewirausahaan pada Kinerja Usaha Kecil dan Menengah (UKM) Sumatera Barat: Analisis Peran Moderasi dari Intensitas Persaingan, Turbulensi Pasar dan Teknologi. Jurnal Manajemen Teknologi, 16.

Wiklund, J. (1999). The Sustainability of the Entrepreneurial Orientation--Performance Relationship.(Statistical Data Included). Entrepreneurship: Theory and Practice, 24(1).

Zimmerer, T. W., \& Scarborough, N. M. (2008). Kewirausahaan dan Manajemen Usaha Kecil. In Salemba Empat. 